\title{
EFFECT OF AMINO ALCOHOL ADMIXTURES ON ALKALI-ACTIVATED MATERIALS
}

\author{
VPLIV AMINO-ALKOHOLNIH DODATKOV NA ALKALNO \\ AKTIVIRANE MATERIALE
}

\author{
Lukáš Kalina*, Vlastimil Bílek Jr., Eva Bartoníčková \\ Brno University of Technology, Faculty of Chemistry, Purkyňova 118, 61200 Brno, Czech Republic \\ Prejem rokopisa - received: 2019-07-15; sprejem za objavo - accepted for publication: 2020-01-29
}

doi:10.17222/mit.2019.150

\begin{abstract}
One of the most important technological problems associated with alkali-activated materials (AAM) is large shrinkage. A possible solution to decrease the extensive drying shrinkage of these materials is the use of shrinkage-reducing admixtures (SRAs). The promising group of SRAs, from the perspective of using in AAMs, are amino alcohols. However, the efficiency of reducing the drying shrinkage strongly depends on their chemical structure. Hence, the study is focused on the molecular architecture of amino alcohol surfactants and its relation to the affected properties of alkali-activated blast-furnace slag systems. Selected amino alcohols were tested in terms of the ability to reduce the surface tension of pore solution as well as to influence the drying shrinkage, hydration mechanism and mechanical properties of AAMs. The study confirms that the length and branching of the alkyl chain linked to the amino group play the key role in SRA efficiency. Amino alcohol surfactants with a high-carbon alkyl chain decreased dramatically both the surface tension and the drying shrinkage, but simultaneously negatively affected the process of alkali activation, resulting in a deterioration of the mechanical properties. Conversely, the addition of $0.5 \mathrm{w} / \%$ of the surfactants with a low molecular weight, such as 2-(Methylamino)ethanol, showed a slight improvement of the compressive strength after $7 \mathrm{~d}$ and $28 \mathrm{~d}$, and at the same time reduced the drying shrinkage by $30 \%$ compared to the reference sample.

Keywords: amino alcohols, admixture, drying shrinkage, alkali-activated materials
\end{abstract}

Eden od najpomembnejših tehnoloških problemov, ki se nanaša na alkalno aktivirane materiale (AAM) je njihov skrček. Možna rešitev za zmanjšanje znatnega krčenja med sušenjem teh materialov je uporaba dodatkov (SRAs) za njegovo zmanjšanje. Obetajoča skupina SRA dodatkov s stališča njihove uporabe za AAM so amino-alkoholi. Vendar je učinkovitost zmanjšanja krčenja med sušenjem močno odvisna od njihove kemijske strukture. Zato so se avtorji tega prispevka osredotočili na študij arhitekture snovi (surfaktantov), ki aktivno vplivajo na površino amino-alkoholov in njihovo povezavo z vzročnimi lastnostmi alkalno aktiviranih sistemov plavžnih žlinder. Izbrane amino-alkohole so avtorji testirali glede na sposobnost zmanjšanja površinske napetosti porozne (mehurčaste) raztopine, kakor tudi vpliv na krčenje med sušenjem, hidracijske mehanizme in mehanske lastnosti AAM. Studija je potrdila da dolge in razvejane vezi alkalnih verig igrajo ključno vlogo pri dodatkih, ki učinkovito zmanjšujejo krčenje. Amino-alkoholni surfaktanti z visoko vsebnostjo ogljiko-alkilnih vezi močno zmanjšujejo tako površinsko napetost kot tudi krčenje med sušenjem, ki pa žal istočasno negativno vpliva na proces alkalne aktivacije, kar posledično vodi do poslabšanja mehanskih lastnosti. Nasprotno temu pa dodatek 0,5 masnih \% površinsko aktivne snovi $z$ majhno molekularno maso kot je 2-(metilamino)etanol kaže rahlo izboljšanje tlačne trdnosti po 7 in 28 dneh in istočasno zmanjšanje skrčka med sušenjem za $30 \%$ v primerjavi z referenčnimi vzorci.

Ključne besede: amino-alkoholi, mešanice, skrček po sušenju, alkalno aktivirani materiali

\section{INTRODUCTION}

From the general point of view, shrinkage-reducing admixtures (SRAs) are organic surfactants that reduce the surface tension of the pore solution of water films that cover the solid surfaces in cementitious materials. ${ }^{1}$ The utilization of SRAs was introduced in 1983 in the study by T. Sato, ${ }^{2}$ where chemical admixtures based on polyoxyalkylene glycol alkyl ether were used. Nowadays, the SRAs are characteristic for their non-ionic nature preventing the adsorption of the additive to the hydration products. The typical chemical compounds used for SRAs belong to the groups of mono-alcohols, glycols, alkylether oxyalkylene glycols and polymeric surfactants or their mutual combination, having a synergic effect in enhancing the shrinkage reduction. The

*Corresponding author's e-mail:

kalina@fch.vut.cz (Lukáš Kalina) vast majority of commercial SRAs are designed for ordinary Portland cements (OPCs); therefore, their efficiency in other inorganic binders may vary significantly.

Alkali-activated materials (AAMs) represent a group of inorganic materials characterized by a pore solution with a high $\mathrm{pH} ;{ }^{3}$ therefore, the molecular design of any organic admixture plays a key role. The same applies to SRAs. The searching for a suitable type of SRA designed especially for AAMs turned out to be complicated, despite the fact that shrinkage is one of the most important technological problems related to many alkali-activated systems. Until now, only several studies have been focused on the organic admixtures affecting the shrinkage of AAMs. ${ }^{4}$

M. Palacios and F. Puertas ${ }^{5}$ studied the effect of polypropylene glycol-based SRA on the shrinkage and other properties of water-glass-activated slag $\left(4 \% \mathrm{Na}_{2} \mathrm{O}\right)$. At a 
relative humidity of $50 \%$ the drying shrinkage of alkaliactivated slag mortars was reduced by approximately $7 \%$ and $35 \%$ for doses of SRA of $1 \%$ and $2 \%$, respectively, while the shrinkage reduction at the relative humidity of $99 \%$ was considerably greater: about $50 \%$ and $75 \%$ for the same doses. Also, C. Bilim et al. ${ }^{6,7}$ used SRA based on polypropylene glycol to mitigate the shrinkage of alkali-activated slag mortars. Again, the drying shrinkage as well as the shrinkage during the moist curing was significantly reduced (up to about $40 \%$ after 180 days) for either liquid sodium silicate or solid sodium metasilicate. The SRA based on polypropylene glycols with different molecular weights was the subject of an investigation by L. Kalina et al. ${ }^{8}$ as well. The study demonstrated that increasing the length of the polymeric chain decreases the surface tension, but also fundamentally changes the pore size distribution, affecting the total shrinkage of alkali-activated blast-furnace slag. The effect of polyethylene glycols on the drying shrinkage of water-glass-activated slag was studied by V. Bilek et al. ${ }^{9}$ The results showed that the efficiency of the shrinkage reduction increased with the increasing molecular weight of the tested glycols.

It is evident that the research in this area was primarily focused on the surfactants based on alkylene glycols. Another alternative may be amino alcohols. These surfactants provide an essential benefit in comparison with alkylene glycols. One of the important properties regarding the SRA's action is the dispersion of used surfactants within the alkaline solution. Amino alcohols show a high dispersibility range in the pore solution because they contain hydrophilic groups, which increase their hydrophile lipophile balance (HLB) value. ${ }^{10}$

Therefore, this study deals with the efficiency assessment of amino alcohol-based SRAs in alkali-activated blast-furnace slag systems. The molecular structure of the used surfactants is evaluated in terms of affecting the character and properties of the prepared alkali-activated materials.

\section{EXPERIMENTAL PART}

\subsection{Materials and sample preparation}

Blast-furnace slag (BFS) with a Blaine fineness of $400 \mathrm{~m}^{2} / \mathrm{kg}$ and the chemical composition given in Table 1 was chosen as the primary aluminosilicate material for the preparation of the alkali-activated samples. The XRD analysis determined more than $90 \%$ of amorphous phase with the content of crystals such as melilite, calcite and merwinite. Sodium water-glass with a silicate module of

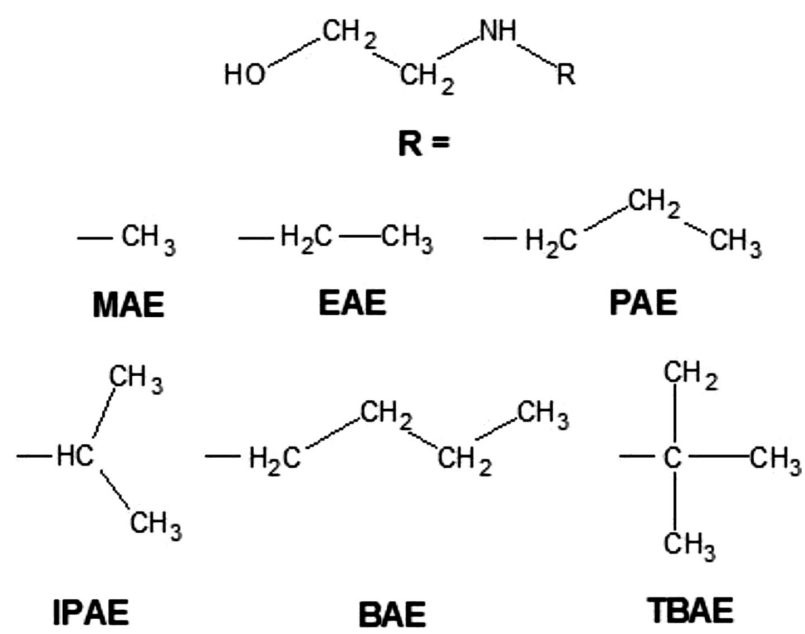

Figure 1: Molecular structure of used amino ethanol surfactants (MAE: 2-(Methylamino)ethanol; EAE: 2-(Ethylamino)ethanol; PAE: 2-(Propylamino)ethanol; IPAE: 2-(Isopropylamino)ethanol; BAE: 2-(Butylamino)ethanol; TBAE: 2-(tert-Butylamino)ethanol)

1.98 was used as the alkaline activator. The $\mathrm{Na}_{2} \mathrm{O} / \mathrm{BFS}$ ratio was adjusted to $4 w / \%$. Amino alcohols with different alkyl chains (summarized in Figure 1) were added in the dosage of $0.5 w / \%$ by mass of BFS.

\subsection{Preparation and physical-mechanical testing of samples}

Alkali-activated BFS mortars were prepared as follows. The sand-to-BFS ratio was 3:1 using three different fractions of siliceous sand specified according to the EN-196-1 standard and the water-to-BFS ratio was adjusted to 0.50 . The mixing and curing processes were carried out at laboratory temperature $\left(25^{\circ} \mathrm{C}\right)$. Mortar samples with the dimensions of $(40 \times 40 \times 160) \mathrm{mm}$ were cast and further cured under a defined relative humidity $(50 \%)$ and then subjected to compressive strength measurements using the strength tester Betonsystem Desttest 3310 after 1,7 and $28 \mathrm{~d}$. The same process of preparation was applied for $(25 \times 25 \times 285)$ mm samples. These species were subjected to the shrinkage measurements based on ASTM C596 (25 ${ }^{\circ} \mathrm{C}$; $\mathrm{RH}=50 \%$ ). The dynamic surface tension of synthetic pore solutions with 128

different amino alcohol admixtures was measured by the tensiometer BPA-800P (KSV Instruments company) using the maximum-bubble-pressure method. The synthetic pore solution was prepared based on the chemical composition of the real pore solution obtained 24 hours after mixing and determined by ICP-OES. It

Table 1: Chemical compositions of blast furnace slag by XRF analysis

\begin{tabular}{|c|c|c|c|c|c|c|c|c|c|c|}
\hline \multirow{2}{*}{ Raw material } & \multicolumn{10}{|c|}{ Chemical composition / $w / \%$} \\
\hline & $\mathrm{SiO}_{2}$ & $\mathrm{Al}_{2} \mathrm{O}_{3}$ & $\mathrm{CaO}$ & $\mathrm{MgO}$ & $\mathrm{SO}_{3}$ & $\mathrm{Na}_{2} \mathrm{O}$ & $\mathrm{K}_{2} \mathrm{O}$ & $\mathrm{TiO}_{2}$ & $\mathrm{MnO}$ & $\mathrm{Fe}_{2} \mathrm{O}_{3}$ \\
\hline blast furnace slag & 34.7 & 9.1 & 41.1 & 10.5 & 1.4 & 0.4 & 0.9 & 1.0 & 0.6 & 0.3 \\
\hline
\end{tabular}


means the same time as the drying shrinkage measurement was started.

\subsection{Isothermal calorimetry}

The evolution of hydration heat was monitored using the TAM Air isothermal microcalorimeter (TA instruments). The measurements of heat evolution were performed at a constant surrounding temperature of $25{ }^{\circ} \mathrm{C}$. When the thermal equilibrium was achieved, the BFS and alkaline activator with a specific SRA were mixed together by injecting the solution into the $15-\mathrm{mL}$ vial and stirring it for $3 \mathrm{~min}$. The samples were made of alkali-activated paste without the standard sand; however, with the same water/BFS and $\mathrm{Na}_{2} \mathrm{O} / \mathrm{BFS}$ mass ratios that were used for the preparation process of the mortars. The heat evolution was recorded as the heat flow immediately after mixing.

\subsection{Microstructure characterization}

Microstructure characterization was performed using scanning electron microscopy (Zeiss EVO LS 10) in secondary-electron mode. The working distance during the observation was $9.5 \mathrm{~mm}$ and the accelerating voltage was set to $10 \mathrm{kV}$. All the samples were sputtered with gold before the measurements.

\subsection{Mercury-intrusion porosimetry}

The total porosity of the samples was determined with a mercury porosimeter (Poremaster Quantachrome Instruments). The working pressure range was from 0.14 $\mathrm{MPa}$ to $231 \mathrm{MPa}$, which covered a pore diameter range from $0.007 \mu \mathrm{m}$ to $10 \mu \mathrm{m}$. The measurements were performed with the following conditions: $\mathrm{Hg}$ surface tension was $0.480 \mathrm{~N} / \mathrm{m}, \mathrm{Hg}$ contact angle was $140^{\circ}$ and scan mode was chosen to average from 11 points. The

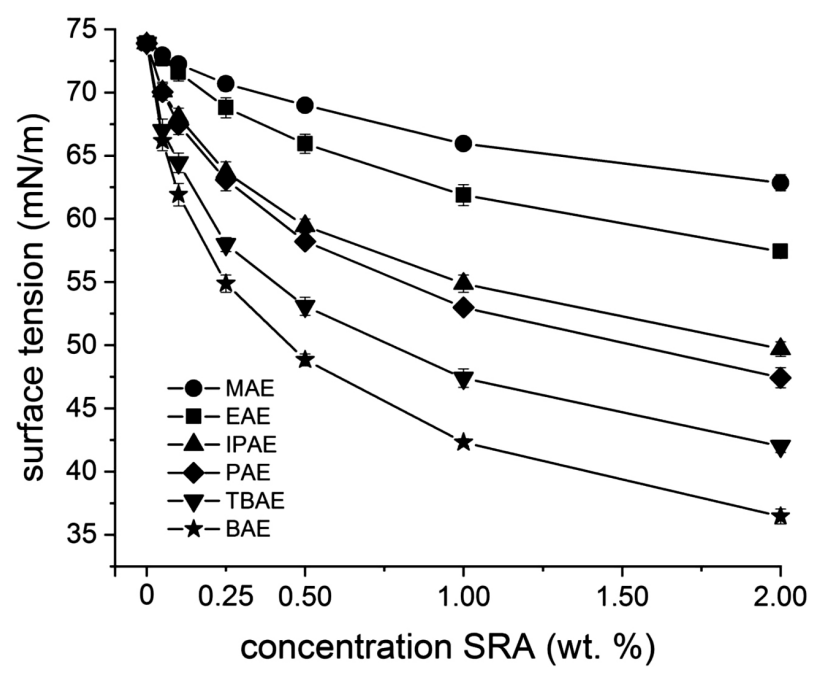

Figure 2: Effect of amino alcohols on the surface tension of the pore solution time (days)

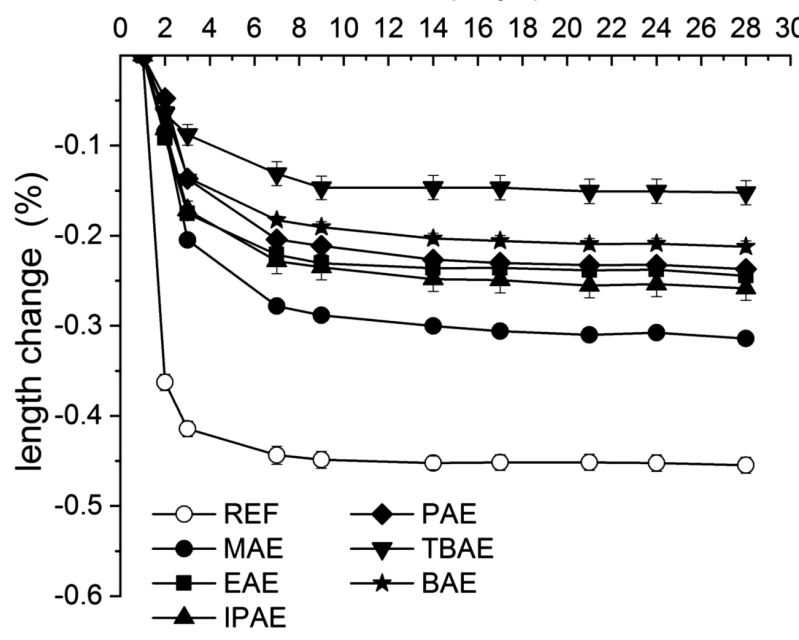

Figure 3: Effect of amino alcohols $(0.5 \%$ by weight of BFS) on the drying shrinkage

intrusion data were normalized by sample weight and volume.

\section{RESULTS AND DISCUSSION}

The mechanism of action of SRA was introduced in the study of Sato et al. ${ }^{2}$ in 1983 . They suggested that the decrease of the surface tension of a cement pore solution tends to reduce the shrinkage due to the elimination of capillary forces. Therefore, the effect of quantity and molecular structure of the used amino alcohols on the surface tension of pore solution were tested. Figure 2 shows that the surface tension decreases with both a large amount of surfactant and the presence of long or branched alkyl substituents. Moreover, the surfacetension measurement provides information about the effective bulk concentration of surface-active admixtures in AAM. In terms of a good ability to decrease the

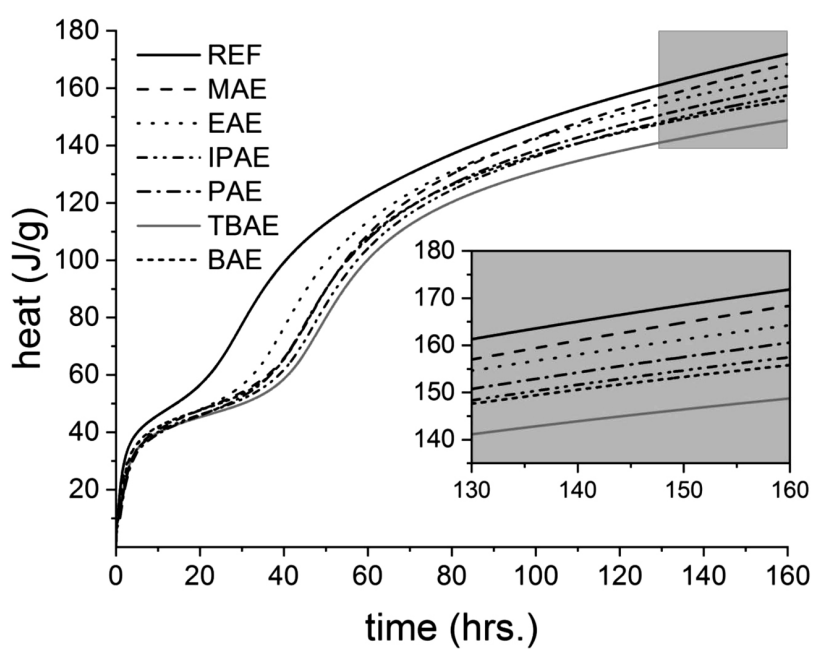

Figure 4: Effect of amino alcohols $(0.5 \%$ by weight of BFS) on the total heat evolution 


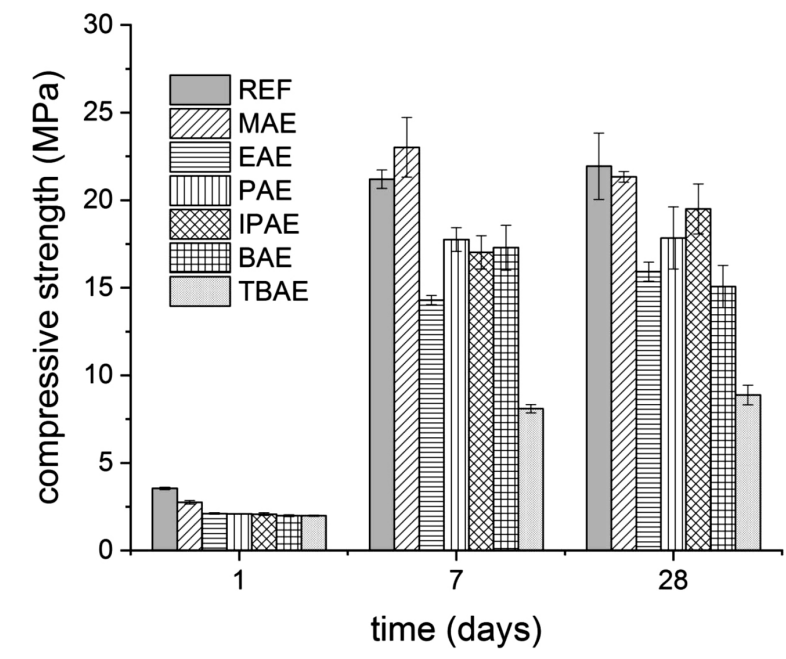

Figure 5: Effect of amino alcohols $(0.5 \%$ by weight of BFS) on the compressive-strength development

surface tension, the addition of $0.5 w / \%$ by mass of BFS was used for the preparation of the mortar samples.

The effect of amino alcohol SRA on the reduction of the drying shrinkage is clear from Figure 3. It can be seen that the surfactants with a long alkyl chain bonded to the amino group tended to decrease the drying shrinkage. Branched chains of substituents also play an

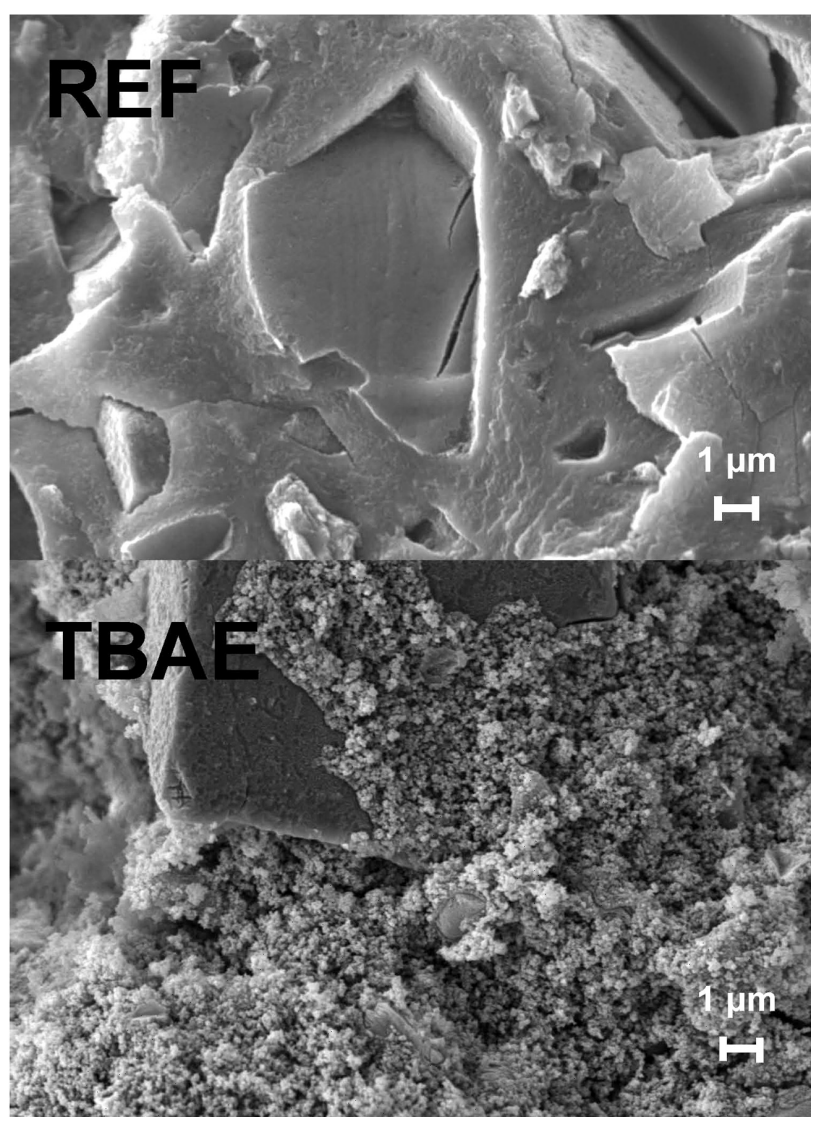

Figure 6: Microstructure of alkali-activated blast-furnace slag without (top) and with 2-(tert-Butylamino)alcohol (bottom) after $7 \mathrm{~d}$

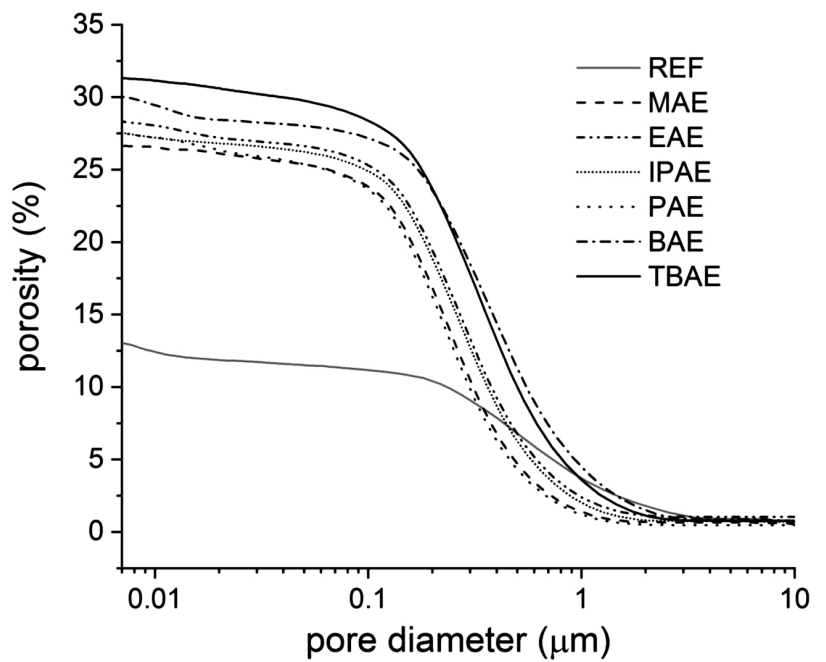

Figure 7: Total porosity measurement of alkali-activated blast-furnace slag with and without amino alcohol admixtures $(0.5 \%$ by weight of BFS) after $7 \mathrm{~d}$

important role. It is evident that 2-(tert-Butylamino)alcohol has a higher ability to reduce the drying shrinkage compared to 2-(Butylamino)alcohol. However, we can see that the surface-tension measurement does not fully correlate with the drying shrinkage evolution. Therefore, the fundamental question arises. Are these two parameters directly dependent on each other? The answer can be suggested by the monitoring of the hydration process. The measurement of the total heat evolution (Figure 4) during the alkaline activation clearly indicates the negative effect of the SRA content, especially during the early ages of the hydration process. This is also confirmed by the development of compressive strengths (Figure 5). The results from the isothermal calorimetry also show that amino alcohols with a low molecular weight such as 2-(Methylamino)alcohol exhibit almost the same total heat evolution as the reference sample without any admixture after $7 \mathrm{~d}$.

It is well known that the total heat evolution is directly related to the binder phase's formation. CASH (calcium-aluminium-silicate-hydrate) gel is the main hydration product in the systems based on the alkaline activation of BFS, which was confirmed by several studies. ${ }^{11}$ The amount of formed CASH gel strongly influences the porosity of the a AAM. The materials with higher content of $\mathrm{CSH}$ or CASH gels create denser structures with small pores. Such systems contain mainly pores with a diameter lower than $10 \mathrm{~nm}$, which greatly affects the magnitude of the drying shrinkage. ${ }^{12}$ Since alkali-activated BFS without SRA has a typical structure, as mentioned above, one would expect the shrinkage strain to be larger than in a material with a coarser microstructure, such as in the case of AAM with TBAE (Figure 6). A similar relationship between the adverse effect of the SRA on the AAM hydration resulting in a lower amount of CASH and a more porous microstructure was also observed in previous studies ${ }^{8,13}$ where 
SRAs-based glycols were used. The changes in total porosity were confirmed by mercury-intrusion porosimetry (Figure 7). The samples with the addition of SRA had a significantly higher porosity compared to the reference sample after $7 \mathrm{~d}$. The direct relationship between drying-shrinkage development and the porosity of samples caused by the addition of specific amino alcohol surfactants was clearly observed.

\section{CONCLUSIONS}

The results suggest that the extent of the drying shrinkage of AAM is mainly controlled by the porosity of the formed structure. In other words, by the quantity of created binder phase, rather than by the decrease of surface tension of the pore solution. Despite the non-ionic character of the used amino alcohol surfactants, the adsorption on the BFS particles, causing the reduction of their solubility in an alkaline environment could be assumed. Promising results indicate the usage of 2-(Methylamino)alcohol. This surface-active admixture in the amount of $0.5 \mathrm{w} / \%$ by mass of BFS did not negatively influence the mechanical properties after $7 \mathrm{~d}$ and $28 \mathrm{~d}$ and reduced the drying shrinkage by $30 \%$ compared to the reference sample.

\section{Acknowledgement}

This outcome has been achieved with the financial support by the project: GA17-03670S, "Development of shrinkage reducing agents designed for alkali activated systems," with financial support from the Czech science foundation.

\section{REFERENCES}

${ }^{1}$ P. C. Aïtcin, R. J. Flatt, Science and Technology of Concrete Admixtures, $1^{\text {st }}$ ed., Elsevier, Cambridge 2015, 613
${ }^{2}$ T. Sato, T. Goto, K. Sakai, Mechanism for reducing drying shrinkage of hardened cement by organic additives, Cement Association of Japan Review, 1983, 52-54

${ }^{3}$ R. R. Lloyd, J. L. Provis, J. S. J. van Deventer, Pore solution composition and alkali diffusion in inorganic polymer cement. Cement and Concrete Research, 40 (2010), 1386-1392, doi:10.1016/ j.cemconres.2010.04.008

${ }^{4}$ J. L. Provis, J. S. J. van Deventer, Alkali Activated Materials, $1^{\text {st }}$ ed., Springer, London 2014, 388, doi:10.1007/978-94-007-7672-2

${ }^{5}$ M. Palacios, F. Puertas, Effect of shrinkage-reducing admixtures on the properties of alkali-activated slag mortars and pastes, Cement and Concrete Research, 37 (2007), 691-702, doi:10.1016/j.cemconres. 2006.11.021

${ }^{6}$ C. Bilim, O. Karahan, C. D. Atis, S. Ilkentapar, Influence of admixtures on the properties of alkali-activated slag mortars subjected to different curing conditions, Materials \& Design, 44 (2013), 540-547, doi:10.1016/j.matdes.2012.08.049

${ }^{7}$ C. Bilim, O. Karahan, C. D. Atis, S. Ilkentapar, Effects of chemical admixtures and curing conditions on some properties of alkali-activated cementless slag mixtures, KSCE Journal of Civil Engineering, 19 (2015), 733-741, doi:10.1007/s12205-015-0629-0

${ }^{8}$ L. Kalina, V. Bilek, E. Bartonickova, J. Krouska, Polypropylene Glycols as Effective Shrinkage-Reducing Admixtures in Alkali-Activated Materials, ACI Materials Journal, 115 (2018), 251-256, doi:10.14359/51701099

${ }^{9}$ V. Bilek, L. Kalina, R. Novotny, Polyethylene glycol molecular weight as an important parameter affecting drying shrinkage and hydration of alkali-activated slag mortars and pastes, Construction and Building Materials, 166 (2018), 564-571, doi:10.1016/ j.conbuildmat.2018.01.176

${ }^{10}$ X. W. Guo, Z. M. Rong, X. G. Ying, Calculation of hydrophilelipophile balance for polyethoxylated surfactants by group contribution method, Journal of Colloid and Interface Science, 298 (2006), 441-450, doi:10.1016/j.jcis.2005.12.009

${ }^{11}$ C. Shi, P. V. Krivenko, D. Roy, Alkali-Activated Cements and Concretes, $1^{\text {st }}$ ed., Taylor\&Francis, Oxon 2006, 376.

${ }^{12}$ S. Mindess, J. F. Young, D. Darwin, Concrete, $2^{\text {nd }}$ ed., Prentice Hall, NJ 2003, 644

${ }^{13}$ V. Bílek Jr., L. Kalina, R. Novotný, J. Tkacz, L. Pařízek, Some Issues of Shrinkage-Reducing Admixtures Application in Alkali-Activated Slag Systems, Materials 9, 462 (2016), doi:10.3390/ma9060462 